\title{
Negligência Grave: a Falta da Exacta Diligentia
}

\section{Serious Negligence: the Lack of Exact Diligentia}

\section{Negligencia Grave: la Falta de Diligencia EXACTA}

\author{
Clayton Reis* \\ Irene Portela**
}

1 Introdução. 2 Conceito. 3 O significado da palavra negligência. 4 O nível de entendimento das pessoas. $5 \mathrm{O}$ sentido da expressão diffeto della inteligenzia na doutrina italiana. 6 A negligência como indicativo da culpa preponderante nos códigos civis alienígenas diante da incuria dos autores. 7 A conduta do bonus pater familiae. 8 A negligência perante os tribunais brasileiros. 9 Os graves efeitos em face da negligência do agente. 10 Considerações finais. Referências.

\footnotetext{
"Magistrado aposentado do TJPR. Pós-Doutor pela Universidade Central de Lisboa. Doutor e Mestre em Direito pela UFPR. Especialista em Responsabilidade Civil pela UEM. Professor Adjunto IV aposentado da UEM. Professor do Curso de Doutorado e Mestrado em Direito da UNICURITIBA. Professor da graduação da Universidade Tuiuti do Paraná. Professor da Escola da Magistratura do Paraná. Membro fundador da Academia Paranaense de Letras Jurídicas do Paraná (APLJ). Membro do Instituto dos Advogados do Paraná (IAP). Membro do Instituto Brasileiro de Estudos de Responsabilidade Civil (IBERC). Parecerista e advogado em Curitiba, Estado do Paraná. Centro Universitário de Maringá, Mestrado em Ciências Jurídicas. Cesumar - Centro Universitário de Maringá. Maringá, PR, BR. E-mail: <claytonreis43@gmail.com>. https://orcid.org/0000-0002-92632392

** Doutora em Direito Constitucional pelo departamento de Direito Público e Teoria do Estado pela Universidade de Santiago de Compostela. Mestre em Administração Pública pela Universidade do Minho. Pós-graduada em Direito da Comunicação pelo Instituto Jurídico da Comunicação pela faculdade de Direito da Universidade de Coimbra. Exerce vários cargos na Escola Superior de Gestão do IPCA, tendo sido, até a presente data, a docente responsável pela Unidade Curricular de Direito Constitucional e de Direitos Fundamentais dos cursos de Solicitadoria e de Fiscalidade. Centro de Investigação Jus-GoV (Justiça e Governação) da Universidade do Minho. Portugal. Email:<iportela@ipca.pt>.http://orcid.org/0000-0002-3570-2200
} 


\section{RESUMO}

Objetivo: A proposta da presente pesquisa detém-se na análise da culpa na modalidade da negligência, por entender que se trata de conduta grave por parte das pessoas, decorrente de um proceder inadequado e desatento em face da realidade vivencial. A negligência, uma das vertentes da culpa, é indicativa da omissão, do descaso, da incúria, da desídia, da desatenção, da displicência e da falta de cuidado e cautela do agente que, no geral, causam danos que poderiam ser evitados, porque previsíveis, se não fosse o descolamento da pessoa diante do caso concreto.

Metodologia: A presente investigação apoia-se no método hipotético-dedutivo, mediante a pesquisa da doutrina, da legislação e da jurisprudência, por intermédio da leitura de livros, de artigos científicos e dos diplomas legais que tratam sobre o tema.

Resultados: A falta de cuidado extrapola os limites da conduta necessária do agente na ordem jurídica, que o jurista qualifica como descaso absoluto; uma verdadeira falta de amor e solidariedade da pessoa. O efeito dessa desídia produz danos de magnitude na pessoa da vítima, com a consequente responsabilização do agente que faltou com os primários deveres de vigilância e o cuidado necessário para evitar o mal não desejado. As pesquisas realizadas no Superior Tribunal de Justiça demonstram inúmeras situações em que a postura negligente do agente produziu danos expressivos, sendo uma grande parte deles de natureza irreversível. É com extremada razão que alguns jurisconsultos, dentre eles Pontes de Miranda, situam a negligência grave ao lado do dolo. A falta de cuidado do agente é tão extremada, que ele procedeu como se tivesse a intenção de produzir o dano. Essa ausência de carinho, de atenção e de cuidado qualifica a pessoa que não se encontra preparada para conviver no ambiente social. $\mathrm{O}$ agente converte-se em um ser humano desconectado dos fatos sociais presentes em todos os segmentos da vida comunitária; submetem a situações de riscos a integridade das pessoas e os valores da sociedade, subvertendo-os por meio do seu comportamento desprovido de razão. Portanto, a negligência, na sua modalidade magna, identifica uma culpa grave que produz danos expressivos e irreversíveis, constituindo uma das formas de culpa com efeitos nocivos mais repelidos pelo ordenamento jurídico. A sociedade contemporânea necessita de paz e confiança nos cidadãos conscientes e responsáveis, que contribuam para a construção de uma comunidade justa, ética e humana.

Palavras-chave: Negligência. Culpa. Efeitos. Magna culpa dolo est.

\section{ABSTRACT}

Objective: The proposal of the present research focuses on the analysis of tort in the negligence modality, as it understands that it is a serious conduct of the agent, resulting 
from an inadequate and inattentive procedure in view of the living reality. Negligence, considered as a type of tort, indicates omission, disregard, malpractice, inattention, nonchalance, and lack of care of the agent, causes damages that could be avoided, due to its foreseeable character, if it weren't for the detachment of the agent regarding the real-life situation.

Methodology: The present investigation is based on the hypothetical-deductive method, by way of research of doctrine, legislation and jurisprudence, through the reading of books, scientific articles and legal diplomas that deal with the topic.

Results: The lack of care goes beyond the limits of the agent's necessary conduct in the legal order, which the jurist qualifies as absolute neglect; a real lack of love and solidarity of the agent. The effects of this gross negligence cause major damages for the victim, with the consequent liability of the agent that acted in disregard with the primary principles of vigilance and caution to avoid the undesired harm. The research carried out before the Superior Court of Justice shows numerous situations in which the agent's negligent posture produced significant damage, a large part of which is irreversible in nature. It is extremely reasonable that some jurisconsults, among them Pontes de Miranda, place serious negligence alongside deception. The agent's lack of care is so extreme that one proceeded as if intended to do the damage. This absence of affection, attention and care qualifies the person who is not prepared to live in the social environment. The agent becomes a human being disconnected from the social facts present in all segments of community life; subject the integrity of people and the values of society to risk situations, subverting them through their reasonless behavior. Therefore, negligence, in its great form, identifies a serious fault that produces significant and irreversible damage, constituting one of the forms of fault with harmful effects most repelled by the legal system. Contemporary society needs peace and trust in conscious and responsible citizens, who contribute to building a just, ethical and human community.

Keywords: Negligence. Tort. Effects. Magna culpa dolo est.

\section{RESUMEN}

Objetivo: La propuesta de la presente investigación se centra en el análisis de la culpa en la modalidad de negligencia, por entender que es una conducta grave por parte de las personas, resultado de un procedimiento inadecuado y desatento ante la realidad viva. La negligencia, uno de los aspectos de la culpa, es indicativo de omisión, negligencia, negligencia, negligencia, desatención, descuido y la falta de cuidado y cautela del agente 
que, en general, provocan un daño que podría evitarse, porque predecible, si no fuera por el desapego de la persona del caso específico.

Metodología: La presente investigación se basa en el método hipotético-deductivo, a través de la investigación de doctrina, legislación y jurisprudencia, a través de la lectura de libros, artículos científicos y diplomas jurídicos que abordan el tema.

Resultados: El descuido va más allá de los límites de la conducta necesaria del agente en el orden jurídico, lo que el jurista califica como negligencia absoluta; una falta real de amor y solidaridad de la persona. El efecto de este desdén produce daños de magnitud en la persona de la víctima, con la consecuente responsabilidad del agente que estuvo ausente de los deberes primarios de vigilancia y cuidado necesario para evitar el mal indeseado. La investigación realizada ante el Tribunal Superior de Justicia muestra numerosas situaciones en las que la postura negligente del agente produjo daños importantes, gran parte de los cuales son de carácter irreversible. Es con extrema razón que algunos jurisconsultos, entre ellos Pontes de Miranda, sitúan la negligencia grave junto al engaño. La falta de cuidado del agente es tan extrema que procedió como si tuviera la intención de hacer el daño. Esta ausencia de afecto, atención y cuidado califica a las personas que no están preparadas para vivir en el entorno social. El agente se convierte en un ser humano desconectado de los hechos sociales presentes en todos los segmentos de la vida comunitaria; ponen en riesgo la integridad de las personas y los valores de la sociedad, subvirtiéndolos a través de su comportamiento sin razón. Por tanto, la negligencia, en su gran forma, identifica una falta grave que produce un daño significativo e irreversible, constituyendo una de las formas de falta con efectos nocivos más repelidas por el ordenamiento jurídico. La sociedad contemporánea necesita paz y confianza en ciudadanos conscientes y responsables, que contribuyan a la construcción de una comunidad justa, ética y humana.

Palabras clave: Negligencia. Culpa. Efectos. Magna culpa dolo est.

\section{INTRODUÇÃO}

O homem é um animal social por excelência ${ }^{1}$. Em decorrência dessa realidade, a existência da pessoa desenvolve-se dentro de um universo regido por normas de

\footnotetext{
${ }^{1}$ Segundo Vecchio (1979, p. 460), pode-se definir a sociedade como, "um complexo de relações pelo qual vários indivíduos vivem e operam conjuntamente, de modo a formarem uma nova e superior unidade. A sociedade é um facto natural determinado pela necessidade que o homem tem de viver com seus os semelhantes. O homem para viver isolado, fora da sociedade, deveria ser (consoante escreveu Aristóteles) - 'um bruto ou um Deus' - ou seja: qualquer coisa de menor ou qualquer coisa de maior que o homem."
} 
condutas, que impõem a observância do princípio insculpido na lapidar frase romana neminem laedere, ou seja, não causar danos a ninguém. Na regra geral, os atos humanos comissivos ou omissivos identificam o grau cultural e intelectual dos agentes que atuam no cenário da vida. Considerando-se a premissa de que viver é conviver - interagir com o outro - ocorrerão situações com múltiplos efeitos em face dessa relação inter-humana. A vida social estabelece a medida do comportamento dos seres que convivem dentro de padrões prescritos em face do modus vivendi das sociedades, como igualmente sofrerá modulações diante das normas jurídicas institucionalizadas pelo Estado. A vida social sempre foi pautada por padrões de conduta que fazem parte da diversidade universal constituinte da personalidade dos agentes titulares do Direito. Sabe-se, no entanto, que a diferença é o componente que integra a personalidade dos seres humanos no ambiente social. Por essa razão, os conflitos de interesses são violados de forma a gerar responsabilidades diversas para os agentes que atuaram comissiva ou omissivamente na produção do ato jurídico.

Nesse quadro, a norma social prescreve ordens de comportamento para refrear os impulsos antissociais e ilícitos como medidas de proteção das pessoas e da sociedade, bem como para prescrever condutas éticas e diligentes, com a finalidade de responsabilizar aqueles que produzirem danos e violarem o padrão de conduta social.

Depois de violado o Direito, o equilíbrio social somente será restabelecido pelo ajuste do comportamento desviante, de acordo com os padrões de diligência e prudência, com o propósito de evitar que o conflito instaurado se dissemine e possa propiciar fatores de desagregação da ordem social, colocando em situação de risco a sobrevivência do próprio Estado. Na maioria das ocasiões, o conflito é o resultado da violação de comportamentos antijurídicos praticados pelos agentes causadores de danos, diante da negligência na observação das regras comportamentais ditadas pela ordem jurídica "creadora y fomentadora de módulos de conducta en el seno del vivir social", no dizer de Sarrión (1993).

As perdas patrimoniais ou extrapatrimoniais poderiam ser evitadas diante da capacidade do agente em avaliar as situações da provável ocorrência de prejuízos, considerando a existência de fatores de riscos potenciais. Não se trata, no caso sub examen, da adoção de medidas futurológicas, senão aquelas que podem ser previstas mediante a utilização da percepção e da razoabilidade, bem como de uma natural análise dos efeitos diante dos fatos atuais.

O homem previdente, em geral, é cauteloso e cuidadoso com as práticas nas vidas social, familiar e profissional. $\mathrm{O}$ agente cauteloso possui o dever da previsão para avaliar os resultados da sua atividade comissiva ou omissiva no ambiente social. Nessa linha de pensamento, caso o motorista imprima velocidade excessiva em seu veículo, deverá assumir os riscos a que se expõe em face da sua conduta imprevidente. 
Em época de coronavírus, o isolamento social representa uma medida de diligência e cuidado, ante a possibilidade de contágio com pessoas portadoras da Covid19. Em situação diversa, o médico que opera seu paciente, sem antes realizar uma avaliação do seu estado clínico, correrá riscos de que a cirurgia resulte no agravamento do estado patológico do seu paciente, em razão do quadro debilitado em que se encontrava antes da intervenção. Se o investidor aplicar seus recursos financeiros em bolsa de valores, sem o cuidado de analisar e proceder a prévia avaliação do mercado de capitais, correrá os riscos de perda substancial do capital investido.

Todos os fatores anteriormente mencionados decorrem da omissão de uma conduta desejada do agente, ou seja, de previdência, cuidado, cautela e observação atenta das circunstâncias nos casos particulares, ou seja, culpa quoad eum quem diligente, provideri potuerit provisum no fuit. Diante dessas ilações, pode-se deduzir que o homem previdente sempre atuará na ordem social e jurídica com o propósito de evitar causar danos, prevendo e tendo conhecimento de que determinadas ações poderão causar lesões aos interesses de outrem - atendo-se ao substrato essencial previsto no princípio neminem laedere de não lesionar o outro. Esse axioma prescreve um modo de comportamento do agente perante a ordem social. Pretende-se investigar esse tipo de conduta por intermédio da presente pesquisa; a razão da sua magnitude no mundo de negócios jurídicos; bem como os conflitos que resultam, na maioria das vezes, da falta de consciência da possibilidade de geração de danos substancialmente lesivos aos interesses de terceiros.

A sociedade contemporânea exige a participação de pessoas conscientes e responsáveis pelos seus direitos e obrigações na ordem jurídica e social; nela ocuparão espaço as pessoas que se amoldam a um modelo de conduta capaz de evitar danos e de proceder dentro de comportamentos responsáveis, destinados à não produção de prejuízos de qualquer natureza a outrem. Na realidade, essa regra se refere, em seu substractum, a um princípio cristão de não fazer ao outro o que não se quer que os outros façam para si, o que indica uma ideia de reciprocidade e consideração na conduta social que exige comportamentos fundados na contínua observância de princípios de respeito aos direitos de integridade física e psíquica do próximo. $\mathrm{O}$ conhecimento dessa realidade depende, em grande parte, dos níveis de consciência e entendimento que devem predominar nos agentes sociais devendo, portanto, evitados porque são previsíveis, se não fosse o descolamento da pessoa diante do caso concreto.

A presente investigação apoia-se no método hipotético-dedutivo, mediante a pesquisa da doutrina, da legislação e da jurisprudência, por intermédio da leitura de livros, de artigos científicos e dos diplomas legais que tratam sobre o tema. 


\section{CONCEITO}

Nesta linha de intelecção, quando se trata de conviver com pessoas e fatos diversos, sempre será necessário medir as ações em razão dos diversos fatores que integram o universo relacional. Miranda (1954, p. 253) alude à circunstância ao afirmar que "faltou, da sua parte, o cuidado que havia de ter, no trato com os outros homens e seus interesses" e, adiante, conclui, "numa e noutra, há falta de cuidado, de amor, de carinho, de atenção" (destaque do autor). "Negligência é descuidar-se".

A diligência, ao contrário da negligência, revela dever de cuidado no processo de escolha dos atos e das atividades por parte do agente, ou seja, a cautela no sentido amplo de quem tem o domínio e o conhecimento dos atos praticados na ordem social, que se busca precaver para evitar prejuízos decorrentes da ação comissiva ou omissiva contraria à ordem jurídica.

A convivência social impõe o dever de observar, com o cuidado necessário, a prática de atos que eventualmente possam causar prejuízo aos direitos do outro Noronha faz alusão às obrigações de consciência ${ }^{2}$. No dizer de Bueres (2001, p. 332), "Se afirma que la culpa es la omisión de la conducta debida, positiva o negativa, para prever y evitar un daño" ${ }^{3}$. O dever de cuidado e diligência na prática dos seus atos de forma consciente e precavida é uma imperiosa necessidade na vida moderna ${ }^{4}$ - uma regra de conduta necessária para viver em paz. Afinal, no dizer de Represas e Mesa (2004, p. 678), "Pero hay un concepto más estricto de culpa, al que vamos referirnos la culpa en el sentido de negligencia, descuido, imprudencia, desidia, falta de precaución, es decir, de daños cometidos sin intención, actuando con descuido, apuro, apresuramiento, etc.”

Nesse caso, o ponto de destaque da negligência encontra-se lapidado na previsão, ou seja, na obrigação do agente de saber o que poderá acontecer e o que certamente acontecerá, caso ele não adote os cuidados necessários para evitar o dano antevisto ${ }^{5}$.

\footnotetext{
${ }^{2}$ Noronha (2003, p. 238): "São obrigações de consciência aqueles deveres que estão para além das obrigações degeneradas e frustradas, mas que correspondem ainda a imperativos sociais de justiça particularmente prementes, que vinculam uma pessoa a realizar uma prestação em favor de outra, ou de outras. O respectivo cumprimento ainda é um ato socialmente necessário, é fortemente exigido pela consciência jurídica geral.”

${ }^{3}$ Segundo Bellapertica citado por Bueres (2001, p. 332), define a culpa como: "uma desviación o extravio - del comportamento del deudor respecto de la conduta normativamente impuesta - desviatio a legis dispositione".

4 Altavilla (1981, p. 179), Os autores ensinam que: "Buscaino, com toda a exactidão, entende por consciência o conhecimento do desenvolvimento no nosso espírito de acontecimentos psíquicos, com a capacidade de percepção, de discriminação, de memória, de raciocínio, de escolha volitiva, de afectividade em geral."

${ }^{5}$ Sarrión (1993, p. 409), proclama que: "La diferencia del mundo de los valores, los fenómenos de imputabilidad no plasman en normas sino en presupuestos, en criterios orientadores de su juicio, que posibilitan su detectación a medida en que se van produciendo, sin que su presunción sea otra cosa
} 
Passmore (2004, p. 415) afirma que, "Se, como o Bispo Butler afirmara: a probabilidade é o guia da vida, o cálculo da probabilidade capacitaria os homens a seguir aquele guia com passos mais confiantes”. Assim, o cálculo da probabilidade envolve, de forma natural, a igual contabilidade da previsibilidade. Pode-se concluir, em face da etimologia da palavra, que a probabilidade é o estudo das chances de ocorrência de um resultado, que são obtidas pela razão entre casos favoráveis e casos possíveis.

Foi com justa razão que os romanos, sempre atentos com os atos comissivos ou omissivos da pessoa que poderiam causar danos a terceiros, prescreveram um modelo de conduta centrado no conceito, inserto no Direito romano, do bonus pater familiae - um chefe de família exemplar que cumpre rigorosamente com os deveres impostos pela ordem jurídica, assim como centrados no princípio de moralidade ${ }^{6}$; todavia, esse comportamento não haverá de ser necessariamente aplicado apenas aos negócios que normalmente impõem uma conduta de cuidados especiais na pactuação das cláusulas contratuais. A contrario sensu, tal comportamento impõe uma conduta continuada em todos os momentos da atividade humana, nas mais diferenciadas ocasiões; passa a representar um modus vivendi de acordo com a norma jurídica, uma forma de atuação constante como proposta de vida no ambiente social. Miranda (1954, p. 261), neste particular, assinala que a

[...] negligência é omissão de diligência exigida no trato ordinário dos homens (destaque do autor), quando, se não tivesse havido essa falta de diligência, se teria evitado o resultado não-querido contrário ao direito; ou seja, a ordem social, qualquer que seja ela, impõe-se a disciplina de conduta.

Conduzir veículos nos grandes centros urbanos, em que a dinâmica do trânsito é intensa, exige cuidado no movimento do veículo e na observância rigorosa das regras que regem a legislação de trânsito. Uma parte acentuada dos diversos acidentes automobilísticos presentes nos centros urbanos decorre, em sua maioria expressiva, da negligência dos motoristas na condução dos seus automotores.

A sociedade moderna, em seus diferentes segmentos, encontra-se conectada a uma série de fatos - celulares, internet, redes sociais, programas informatizados, controles de dados, atividades bancárias e atividades negociais, entre diversos outros; são continuamente violados e exigem severa diligência àqueles que atuam nesses ambientes. A mera negligência poderá resultar em graves e irreversíveis danos aos seus usuários?

que un medio de facilitación de la prueba, por cuanto hay hechos que no pueden surgir sin haber mediado culpa."

${ }^{6}$ Miranda (1954, p. 254): "O homem normal, o homem diligente, para o patriarcalismo do direito romano, havia de ser o bom pai de família."

${ }^{7}$ Miranda (1954, p. 254) alude ao seguinte fato, "A medida do cuidado, para se saber desde onde e desde quando ele falta, é dado pelas relações inter-humanas, é social, objetiva, e não individual, intima, subjetiva. Não basta a conduta, para ficar fora da zona espacial e temporal da negligência, o ser o que é 
Certamente que a culpa na modalidade de negligência não será atribuída às pessoas, na maioria das vezes, mais preparadas cultural e intelectualmente, nem mesmo ao especialista nas Ciências Jurídicas. A diligência é um atributo pessoal daqueles que sabem viver em sociedade respeitando os direitos do outro. ${ }^{8}$ Para o exercício dessa prerrogativa, será necessário conhecer seus próprios limites, assim como os limites do próximo e, igualmente, as restrições das normas sociais que comandam a vida das pessoas. A vetusta regra alicerçada no princípio de que o direito de uma pessoa termina onde começa o direito da outra representa um ditado áureo, consistente no controle pessoal das ações com o propósito de não causar dano a ninguém - alterum non laedere. Para atingir essa finalidade, o homem diligente será precavido, medindo seus pensamentos, atos e palavras, com o propósito de evitar que possam gerar efeitos nocivos no ambiente social ${ }^{9}$.

A palavra verbalizada deve ser utilizada de forma mansa, pacífica e precisa para expressar o pensamento que se concretiza por meio da ação ou da omissão, ao tempo em que deve ser despida do interesse de gerar atrito ou ser interpretada de forma errônea. A linguagem, quando elaborada de forma previdente, clara e precisa não produzirá efeitos diferentes do pretendido pelo agente que a verbaliza. O segredo nesse processo de relações pacíficas se denomina previsibilidade.

Segundo Farias, Braga Netto e Rosenvald (2015, p. 175), "cuida-se de uma previsibilidade pessoal, na qual o agente não prevê o resultado, que podia e devia prever". A previsão é o elemento determinante da negligência, visto que a pessoa tem a obrigação de saber o resultado da sua ação. Mesmo os incultos sabem que sua ação ou omissão produzirá os efeitos desejados pela pessoa no ambiente social ${ }^{10}$. Bueres (2001, p. 319) ensina que:

corrente, se o corrente pelos maus costumes é a negligência mesma. Daí o problema técnico de se dizer em que consiste a diligência: é seleção, escolha, cuidado."

${ }^{8}$ Farias, Braga Netto e Rosenvald (2015, p. 176): "Igualmente equivocada será quaisquer associação de padrões sociais de conduta com a vetusta noção do homem médio, até mesmo por se considerar que de um ser humano medíocre muito pouso se exigirá em termos de cuidado e diligência, quando, no terceiro milênio, procuramos por parâmetros elevados de cautela que sejam coerentes com o convívio em sociedade tecnológica".

${ }^{9}$ Vecchio (1979, p. 571): "No tocante à moralidade, encarada pelo aspecto extrínseco, reduz-se ela sempre ao "dever de operar como os outros operam". Mas esta fórmula corresponde tão só a uma imagem invertida da outra. A verdade é precisamente, o oposto: o sujeito deve, por si, atingir a norma universal das ações, de tal guisa que, assim como ele opere, os outros possam também operar. $\mathrm{O}$ princípio da legislação universal é, pois, a nossa própria consciência."

${ }^{10}$ Passmore (2004, p. 416): "Condorcet treinado como matemático, tentou demonstrar em detalhes, como o cálculo das probabilidades poderia ser usado como uma forma de determinar não apenas as leis sociais pelas quais a histórias humanas era regida, mas também a estratégia política mais sábias a ser numa mesma situação. Se o cálculo das probabilidades podia ser empregado com êxito na análise do jogo - o melhor paradigma para a casualidade e a incerteza - não havia razão para que não fosse utilizado com igual êxito na análise da decisão política." 
Se ha dicho, por ejemplo, que la culpa consiste en un error de conducta, y naquellos que no habría cometido una persona prudente y cuidadosa, preocupada por tener en cuenta las eventualidades desgraciadas que pudieran derivarse para otro; portanto, a pessoa consciente e responsável deverá fiscalizar com o cuidado necessário seu comportamento, prevendo que todo desvio da ordem normativa produzirá danos ao patrimônio de outrem.

É recorrente que o autor do ato comissivo ou omissivo seja completamente desatento no dever de prever, não se atentando aos efeitos do seu procedimento - essas pessoas são as incivilizadas, ou seja, aquelas que vivem no ambiente social e estão desconectadas dos efeitos da ação ou omissão ilícitas ${ }^{11}$. Tais pessoas vivem dentro do seu próprio universo, sem percepção das realidades que se operam no mundo exterior ${ }^{12}$. Segundo a ótica de Farias, Braga Netto e Rosenvald (2015, p. 176), “A culpa, segundo Bianca, consiste na ausência da atenção que ocorre normalmente na vida de relação daquilo que é especialmente pedido pela função do sujeito ou tipo de sua atividade." Pode-se, por conseguinte, entender, de acordo com os autores nominados, que se está diante de uma transposição da culpa ética ou jurídica para uma culpa social.

A gravidade do descaso da pessoa destaca-se, no entendimento de Passmore (2004, p. 416), quando

[...] ela seria recomendada não apenas como um instrumento para compreender o comportamento econômico e as relações internacionais, mas até mesmo como um método confiável para determinar a melhor política moral a ser adotada (grifo do autor).

Por essa razão, Passmore afirma que, no século XVIII, a probabilidade foi adotada como um guia para a tomada de decisão. Será necessário, portanto, que o sentido de percepção ou avaliação, do que é previsível ocorrer, desenvolva-se de forma a evitar situações que agravem ou tornem mais onerosas às alternativas escolhidas ${ }^{13}$, esclarecendo-se que elas produzirão efeitos diversos no ambiente social e não somente

\footnotetext{
${ }^{11}$ Vecchio (1979, p. 570): "Da referida lei surge, quanto ao primeiro aspecto, o dever moral, que sobre o homem, só por ser homem impede, dele exigindo que supere os motivos externos, os impulsos particulares e sensíveis, de sorte a nos seus próprios actos imprimir o selo universal da razão. Ao homem cumpre, em suma, transcender a sua existência física de individuo pelas suas deliberações para se afirmar na sua qualidade de princípio, de ser racional ou universal, até a si mesmo se identificar ao ser dos outros sujeitos."

${ }^{12} \mathrm{O}$ autor alude ao fato de que, "quando o agente sabe ou tem a obrigação de saber que sua ação contraria um comando jurídico, e mesmo assim age, pratica um ato ilícito (isto é, antijurídico e culposo)." (NORONHA, 2003, p. 368).

${ }^{13}$ Noronha (2003, p. 369), o autor ensina que: "Se no ato ilícito a vontade do agente é sempre relevante, não haverá ilicitude (subjetiva), quando não nele houver vontade e consciência da ação que pratica, ou da omissão em que incorre. Por isso é que os atos danosos praticados por inimputáveis são antijurídicos, mas não chegam a ser ilícitos, porque têm por autores pessoas não passíveis de juízos de censura."
} 
para quem realizou a previsão errada ${ }^{14}$. Nessa linha de pensamento Diderot ${ }^{15}$ chega a afirmar que "somos criminosos apenas porque julgamos erroneamente"

Ao abordar o tema da negligência, Gonçalves (2017, p. 35), afirma que “a negligência é a falta de atenção, ausência de reflexão necessária, uma espécie de preguiça, em virtude da qual deixa o agente de prever o resultado que podia e devia ser previsto". Ora, essa espécie de preguiça relata uma situação de pouca consideração do agente pelos efeitos que produzirá a sua ação omissiva; esse fato indica uma culpa de grandes proporções em face das suas nefastas consequências; representa um descaso à pouca ou à completa ausência de importância atribuída aos resultados envolvendo terceiros, ou seja, a falta do cuidado necessário da pessoa ou a sua errônea avaliação diante dos julgamentos equivocados que produzirão graves efeitos.

\section{O SIGNIFICADO DA PALAVRA NEGLIGÊNCIA}

A palavra negligência tem múltiplos significados na esfera da responsabilidade civil. $\mathrm{O}$ principal deles se confere à existência do descaso que as pessoas demonstram em relação aos diversos atos comissivos ou omissivos declarados no mundo das relações obrigacionais. $\mathrm{O}$ ato negligente revela um comportamento inadequado do agente no ambiente social, que deve ser pautado pela observância de normas de conduta fundadas em respeito e consideração para com o outro.

A palavra negligência indica um substantivo feminino que demonstra, por quem atua no ambiente das relações, a falta de cuidado, de aplicação, de exatidão, de interesse ou de atenção. Nesse caso haverá descuido, displicência, desatenção, desleixo, desmazelo ou preguiça. Poderá, ainda, representar a ausência de motivação, de disposição, de interesse, de vigor e, até mesmo, de indolência ou de incúria, ou seja, a falta, mesmo não intencional, da pessoa que omite cumprimento de um ato imposto pela ordem jurídica.

Schreiber (2018, p. 615) alude ao fato de que "hoje a culpa é vista como a violação a um dever jurídico." O que se observa, na maioria das vezes, é que o agente que a prática não observa o dever de cuidado, considerando que todos os atos executados no ambiente social exigem condutas compatíveis, moderadas e previdentes ${ }^{16}$.

\footnotetext{
${ }^{14} \mathrm{O}$ autor adverte que, "Uma percepção equivocada do interesse, Condorcet similarmente sugere, é a causa mais comum de ações contrárias ao bem estar geral; a violência de nossas paixões é o resultado tanto dos hábitos que adotamos através de uma errônea avaliação ou da nossa incapacidade em não sabermos como nos precaver delas - e em ambos os casos a origem está na ignorância." (PASSMORE, 2004, p. 421).

${ }^{15}$ Segundo relata Passmore (2004, p. 421).

${ }^{16}$ Os autores lecionam que "La teoria de la responsabilidad civil se asienta sobre el concepto de previsibilidad; solo los resultados previsibles son imputables al autor del acto, puesto que sólo ellos se encuentran relacionados casualmente de una manera adecuada con el hecho generador del daño." (REPRESAS; MESA, 2004, p. 672).
} 
Ora, até os animais movimentam-se por meio dos seus reflexos de previsão, que se processa em seus cérebros, de não atacar vítimas maiores e mais preparadas para o revide, porque sabem que os efeitos serão nocivos para eles. $O$ ato de prever é um mecanismo natural presente em todos os seres, representando um meio operacional instaurado pela natureza na mente dos animais racionais e irracionais.

Segundo o escólio de Miranda (1954, p. 253),

Negligência é descuidar-se; vem de nec-ligere, isto é, de legere, ler, que é reunir, como diligenciar, que é escolher, selecionar (di-) para cuidar, e como inteligência (inter-ligere, intelligere). A falta (nec) de cuidado, de (di) ligentia, ou consiste a) em ato imprudente (que não prevê, improvidentem; imprudentem, em forma sincopada, ou b) em omissão das medidas que incumbiam a quem devesse prever. Mas no antigo direito romano a) era culpa e b) era negligentia.

Portanto, pode-se deduzir que a negligência significa a ausência de reflexão, dado que o agente não prevê o que poderá acontecer em face dos seus atos, segundo pontifica Miranda (1954, p. 262), "[...] responde pela culpa, pois havia de refletir antes de proceder" (destaque do autor). Ora, se não se analisou a situação de forma precavida, o agente assumiu os riscos dos fatos que possivelmente ocorrerão em razão dos atos impensados.

O que se evidencia na construção do pensamento é a circunstância da falta da ponderação ou, ainda, a inexistência de cuidado na prática das atitudes que produzem efeitos no campo do Direito e das relações humanas. Na contemporaneidade, o homem aprendeu a refletir antes de decidir. Esse processo analítico representa uma conquista da inteligência humana, bem como decorre do acentuado desenvolvimento científico presente na atualidade, que exige uma construção cuidadosa em todos os atos da vida privada e social ${ }^{17}$.

Quando o agente procede de forma impensada, sem refletir sobre seus atos comissivos e omissivos, poderá gerar danos expressivos, o que equivale a afirmar que age com dolo, ou seja, com o propósito de produzir prejuízos. Nessas linhas de pensamento, Rizzardo (2007, p. 10), ao citar Serpa Lopes, assinala que, "[...] se, do ponto de vista moral, sensível é a diferença entre aquele que age dolosamente e o que procede com

\footnotetext{
17“A própria noção de culpa transformou-se ao longo do tempo. Se, antes, a culpa era vista como uma espécie de 'pecado jurídico' (Péché juridique, na expressão de Paul Esmein), a exigir a prova de uma falha psicológica do agente que pudesse ser considerada "reprovável" à luz das circunstâncias concretas, hoje a culpa é vista como a violação de um dever jurídico. A passagem dessa noção psicológica de culpa para uma noção normativa de culpa reflete a necessidade de superar antigas dificuldades de aferição da culpa, que faziam com que se exigisse da vítima verdadeira probatio diabólica e que acabariam contribuindo para o surgimento da responsabilidade objetiva, como se verá adiante." (SCHREIBER, 2018, p. 615).
} 
absoluta negligência, entretanto, em relação aos efeitos, são de gravidade idêntica, em razão do que muito natural a exigência de uma idêntica repressão civil.”

Dessume-se dessa assertiva que a negligência grave demonstra uma absoluta apatia da pessoa no seu modo de agir no âmbito social; o descaso para com os efeitos da ação nefasta, que revela a natural indiferença do agente. Ora, essa circunstância ressalta que a falta de cuidado ou de cautela na produção do ato pelo autor do dano foi edificada em sua mente sem a mínima preocupação com os prejuízos previstos. Afinal, nas linhas pontuadas por Pontes de Miranda (1954, p. 263, grifo do autor), "A negligência grave supõe que o agente podia prever o resultado e o previu." Ora, se o animal é perigoso, dever-se-ia prever que atacasse e produzisse danos significativos na vítima.

A conexão é imediata e identifica uma pessoa completamente desconectada dos procedimentos necessários de quem convive no ambiente social ${ }^{18}$. Por essa razão, essa modalidade de negligência deve ser compreendida como o descaso completo do agente, considerando a omissão ou a falta do cuidado necessário no ambiente social. Tal ausência de atenção indispensável agrava-se na medida em que o agente não tem consciência de que as relações de sociabilidade devem ser pautadas por princípios éticos e normativos que conferem a estabilidade coletiva.

\section{O NÍVEL DE ENTENDIMENTO DAS PESSOAS}

No universo dos relacionamentos humanos, o que predomina é a manifestação ou a exteriorização dos atos voluntários imanentes da pessoa, que representam a expressão da sua vontade de agir no ambiente relacional. Segundo o escólio de Miranda (1954, p. 372), "Ato humano é fato produzido pelo homem; às vezes, não sempre pela vontade do homem". Em geral, esses atos manifestam o desejo espontâneo que se formou no subconsciente da pessoa com o desejo de produzir um determinado resultado. Os referidos atos exigem consciência e discernimento do agente - o demente não sabe o que faz, ao mesmo tempo que faz o que não sabe. De qualquer forma, a vontade do agente é ponto determinante, na medida em que estabelece seu desejo de produzir determinado efeito na esfera do Direito. Assim, há atos e fatos realizados no mundo físico sem a intervenção ou manifestação da pessoa, como os fatos de força maior que não ingressam no universo jurídico porque estão ausentes a imputabilidade e a reprovabilidade de quem os produziu.

18 "Pero hay concepto más estricto de culpa, al que vamos a referirnos: la culpa en el sentido de negligencia, descuido, imprudencia, desidia, falta de precaución, es decir de daños cometidos sin intención, actuando con descuido, apuro, apresuramiento, etv". (REPRESAS; MESA, 2004, p. 678). 
Miranda (1954, p. 254) assinala que "não se sabe ao certo a que tempo remonta o conceito de diligentia quam suis, isto é, de diligência que a pessoa sói ter em negócios próprios ou assuntos próprios - diligentia quam in suis rebus praestare solet". As pessoas já nascem impregnadas com o conceito de cuidado; na verdade, um instinto natural de preservação diante dos riscos de danos que se encontram presentes no ambiente físico repleto de manifestações sociais e da natureza.

Com o desenvolvimento das sociedades no transato da história, as normas de convivência tornaram obrigatórios determinados comportamentos para impedir a prática de atos potencialmente lesivos a terceiros - por esse motivo, surge o preceito universal e fundamental de convivência consistente no princípio neminem laedere. "Assistiu-se ao surgir do dever de ter cuidado, do dever de diligência", destaca Pontes de Miranda (1954, p. 256, grifo do autor).

O paradigma criado consiste no dever de zelar o patrimônio do outro, como se gostaria que os seus próprios pertences fossem preservados com o devido cuidado e zelo. Nesse caso, a lição sempre precisa de Miranda (1654, p. 256) o qual assinala que "o depositário há de ter, na guarda e conservação da coisa depositada, o cuidado e diligencia (sic) que costuma ter com o que lhe pertence (art. 1.266, § 1, do CCB-16)", correspondente ao art. 629 do Código Civil de 2002.

Ao analisar-se sobre outro aspecto, o dever de cuidado, necessário na prática dos atos na vida social, implica determinado nível de percepção desses mesmos atos e de fatos no mundo físico e relacional, isto é, os seres humanos devem estar atentos, por meio do uso dos seus sentidos, diante dos fatos que os circundam, de maneira que, quanto maior for o grau de percepção, maior será a oportunidade de evitar danos que ocorrem na sua atmosfera. Para tanto, devem utilizar-se do cuidado indispensável para excluir ou atenuar os prejuízos causados pelo seu descaso ou pela não percepção em face dos fatos que estão em vias de acontecer ${ }^{19}$. Na realidade, exigir-se-á da pessoa um sentido adequado, relacionado ao fato em vias de ocorrer, antevendo tais acontecimentos. Ao tratar do tema em estudo, Bueres (2001, p. 321) esclarece que "prever es proyetar un juicio en el porvenir prognosticando que de la conducta del agente se seguirá un resultado". O que se evidencia contrariamente a esse comportamento é a incúria, o descuido ou a ausência da conduta necessária para evitar-se o dano previsto, quando o agente não empregou as cautelas necessárias para evitá-lo. Nessa mesma linha de intelecção, Bianca (1994, p. 156) proclama que "Danno prevedibile è il danno cui è probabile l'accadimento secondo um giudizio normalmente diligente". Ora, a expressão, segundo um juizo normalmente diligente,

\footnotetext{
${ }^{19} \mathrm{O}$ autor enfatiza sobre o tema que: "Previsivel é o resultado quando a previsão do seu advento pode ser exigida do homem comum, normal, do indivíduo de atenção e diligência ordinárias. Pelo critério subjetivo a previsibilidade deve ser aferida tendo em vista as condições pessoais do sujeito, como idade, sexo, grau de cultura, etc.”. (CAVALIERI FILHO, 2014, p. 51).
} 
indica que todas as pessoas que atuam no mundo de relações devem ser diligentes, cautelosas e cuidadosas diante do seu modus faciendi.

Parece, salvo melhor juízo, que a negligência está intimamente associada à falta de um grau de percepção das pessoas no mundo de relações. Quanto menor for o nível de percepção, maior será o grau de negligência do agente ${ }^{20}$. Os brutos ou insensíveis têm um baixo nível de cuidado e, por consequência, encontram-se mais propensos a causar danos em virtude da sua escassa possibilidade de prever e/ou antecipar os acontecimentos danosos. No sentido contrário, o estrategista, em razão da sua apurada percepção dos movimentos do adversário, será capaz de traçar estratégias para sair vitorioso em seu confronto.

Durante a Segunda Grande Guerra, os alemães concentraram suas tropas no porto de Calais, na França, sabidamente o caminho mais curto a partir da Inglaterra para o desembarque no Continente das tropas aliadas. No entanto, o desembarque ocorreu na Normandia, o caminho mais curto, pois os estrategistas das forças aliadas tiveram percepção contrária à dos alemães.

No mundo negocial, toda atividade empresarial encontra-se associada à percepção mercadológica da aceitação do produto no mercado de consumo aliado à igual percepção do modus operandi ou dos meios utilizados para superar os produtos das empresas concorrentes. Nessa ordem, Passmore (2004, p. 419, grifo do autor) adverte que, "Em primeiro lugar, trata-se agora de um problema técnico determinar o que é o melhor a fazer, aconselhar como agir, ao que tudo indica, só poderia propriamente ser feito por aqueles que são peritos em calcular consequências.”

Diante de tais evidências, é conclusivo afirmar que uma pessoa extremamente diligente é um expert no cálculo das prováveis consequências que seus atos produzirão. Portanto, a previsão ${ }^{21}$ para evitar o dano revela a conduta da pessoa responsável e cuidadosa na prática de atos no mundo de relações em que imperam interesses múltiplos, considerando que, na maioria das vezes, violam interesses dos indivíduos envolvidos nesse processo.

Bianca (1994, p. 143) relata que "Il dovere de danneggiato di cooperare per limitare la responsabilità del danneggiante reentra nel generale dovere dil correttezza, quale impegno di solidarietà che impone ala parte di salvarguadare l'utilità dell'altrane ilimiti di uma pprezzabile sacrificio."

A expressão utilizada pelo autor ao afirmar “... que impõe à parte de salvaguardar a utilidade do outro de limitar um apreciável sacrifício" revela um princípio de solidariedade

\footnotetext{
${ }^{20} \mathrm{O}$ autor alude ao critério subjetivo da diligência ao afirmar que, "Pelo critério subjetivo a previsibilidade deve ser aferida tendo em vista as condições pessoais do sujeito, como idade, sexo, grau de cultura etc." (CAVALIERI FILHO, 2014, p. 51).

21 "La prévention est une fonction de la responsabilité civile qui ne peut guère être discutée". (TUNC, 1981, p. 134).
} 
que deve predominar nas relações bilaterais, com a finalidade de propiciar a melhor solução na concretização dos negócios jurídicos ou, ainda, com a finalidade de que os interesses sejam atendidos de forma igual e solidária.

Nas relações bilaterais, o sistema contratual pátrio impede a onerosidade excessiva dos contratos (art. 478 do CC), bem como o enriquecimento ilícito (art. 884 do $\mathrm{CC}$ ) de uma das partes nas relações bilaterais. Na mesma prática dos atos negociais, torna-se necessária uma postura de diligência e cuidado dos contratantes para atingir o equilíbrio e a solidariedade que devem predominar no mundo dos negócios.

\section{O SENTIDO DA EXPRESSÃO DIFFETO DELLA INTELIGENZIA NA DOUTRINA ITALIANA}

Todos os atos humanos que ingressam na vida jurídica denotam condutas que expressam a vontade das pessoas e de agentes em manifestarem-se no mundo dos interesses; dessarte, os atos que ocorrem no universo das relações humanas devem, necessariamente, ser conscientes, de maneira que os agentes tenham pleno conhecimento das suas declarações e dos efeitos que produzirão.

Miranda (1954, p. 202) afirma que "A omissão - e não só o ato positivo - entra no rol das causas"; na mesma página, adiante, alude que "[...] a omissão, para causar responsabilidade, tem de implicar ação, ser como a ação"; portanto, entender-se-á a omissão não como a inércia ou a ausência de manifestação do agente, mas sim como uma ação capaz de produzir danos a terceiros, em virtude da ausência da conduta necessária prevista para evitar a ofensa ao patrimônio de outrem, ou seja, uma contrariedade ao Direito. Os franceses denominam de faute $d u$ service a falha na prestação do serviço devido, que o Estado ou a parte deixou de realizar ou a realizou de forma deficiente, em razão da falta do cuidado necessário em sua execução, cuja imperiosa realização não se concretizou por falta de diligência do executor.

Diante do ordenamento de ideias, Miranda (1954, p. 253, grifo do autor) adverte que, na omissão em relação ao agente, “... faltou, da sua parte, o cuidado que havia de ter, no trato com os outros homens e seus interesses", para, na sequência, concluir: "basta que ignore algum fato, ou regra jurídica, que devesse conhecer". Logo, segundo o jurista, a negligência conduza a ideia de uma espécie de falta de cuidado da pessoa nos tratos com as realidades da vida, com as quais se depara de forma contínua. A título de ilustração, menciona-se o dever do cuidado necessário (I) no tráfego de veículos nos grandes centros urbanos, (II) nas atividades profissionais e (III) nas relações familiares, laborais e sociais, dentre inúmeras outras situações.

Um exemplo do que se descreve no presente trabalho seria o evento do cavalo que adentrou uma pista de rolamento e, ao colidir com um veículo, produziu danos de 
grande magnitude ao condutor, em razão da ausência de prestação de serviço da concessionária e diante da sua negligência em oferecer condição de segurança na trafegabilidade. Houve a mesma ocorrência com relação ao dono do animal, que deixou patenteada a sua negligência no dever de vigilância do animal para mantê-lo dentro da sua propriedade com a segurança necessária. Essa falta de percepção revela um defeito na personalidade em seus poderes de análise e prevenção dos acontecimentos que decorrerão dos atos do agente. Todos os seres vivos da natureza foram dotados de mecanismos de prevenção que são acionados diante de perigos, bem como da habilidade de preverem a ocorrência de prováveis danos ${ }^{22}$.

$\mathrm{Na}$ contemporaneidade, convive-se com uma enorme variedade de riscos em razão do extraordinário desenvolvimento da ciência e da tecnologia. Essa realidade se deve ao manuseio de equipamentos eletrônicos no interior das residências - microondas, fornos elétricos, fornos a gás, aquecedores elétricos, carregadores de celulares e outros - bem como no trânsito - na locomoção nos grandes centros urbanos por meios terrestres, marítimos, aéreos e ferroviários que oferecem infindáveis probabilidades de danos. Conhecendo os apontados riscos, as pessoas desenvolveram, naturalmente, mecanismos de prevenção em face das probabilidades de prejuízos gerados por essas situações.

Não se trata de estabelecer um padrão social de conduta desejado ao cidadão, consciente dos riscos de possíveis danos, para adotar um determinado padrão de comportamento social ${ }^{23}$. No universo dos riscos, seria impossível estabelecer um modelo de conduta da pessoa diante das variadas possibilidades de danos que ocorrem na sociedade tecnológica. O que se exigirá, nesses casos, será que as pessoas desenvolvam mecanismos psíquicos de análise e prevenção dos perigos da atividade, diante das inúmeras possibilidades de danos. Assim, o homem-moderno estará atento às realidades do mundo modelado por elevada tecnologia, com o propósito de pautar sua conduta ${ }^{24}$ para evitar a ocorrência do dano.

\footnotetext{
22 "A norma possui uma função preventiva, pois já insere em seu bojo um cálculo de previsão, segundo a qual a desobediência à norma já induz à culpa, independentemente da valoração da conduta pelo próprio agente”. (FARIAS; BRAGA NETTO; ROSENVALD, 2015, p. 176).

${ }^{23}$ Os autores aludem ao fato de que, "Igualmente equivocada será qualquer associação de padrões sociais de conduta com a vetusta noção do "homem médio", até mesmo por se considerar que de um ser humano medíocre muito pouco se exigirá em termos de cuidado e diligência quando, no terceiro milênio, procuramos por parâmetros elevados de cautela que sejam coerentes com o convívio em sociedades tecnológicas". (FARIAS; BRAGA NETTO; ROSENVALD, 2015, p. 176).

24 "La culpa siempre lleva implícito un defecto de conducta; es un concepto de carácter normativo que se funda en que el sujeto debía hacer algo distinto de lo que hizo y le era exigible en esas circunstancias: consiste o en no prever el daño, no obstante ser previsible; o bien, en preverlo, pero sin tomar los recaudos o observar la conducta necesaria para evitarlo". (REPRESAS; MESA, 2004, p. 679).
} 
Tunc (1981, p. 59) ensina que "c'est la négligence: um certain manque d'attention aux conduites ou aux conséquences de as conduite", ou seja, o agente tem o dever de atuar com cuidado na prática de todos os atos na vida moderna, bem como a obrigação de conhecer os efeitos da sua ausência de diligência necessária para evitar o dano antevisto.

Observa-se, no momento presente, que o conceito de dano evoluiu de forma extraordinária na sociedade moderna. Todos os setores industriais, particularmente o automobilístico, farmacêutico e alimentício desenvolveram mecanismos científicos de prevenção de danos para esquivar-se da sua ocorrência ou, pelo menos, minimizá-los da forma mais ampla possível. Todavia, ainda não se atingiu o conhecimento científico de eliminação absoluta do dano descrito na teoria do risco do desenvolvimento, em função de inexistir, até o presente momento, o conhecimento científico que elimine completamente os riscos de danos. É a teoria do risco do desenvolvimento que vem sendo sufragada pelos doutrinadores e tribunais brasileiros como risco inerente dos fabricantes, não os desonerando da responsabilidade civil decorrente do produto que causa danos ao consumidor.

No que tange à pessoa, é perceptível que a ausência de previsibilidade revela, em seu discernimento, uma deficiência psíquica da pessoa em seu processo de prevenção ${ }^{25}$. Os loucos ou os dementes são destituídos desse mecanismo de pós-visibilidade porque não têm discernimento, que é a capacidade ou faculdade de escolher, ter critério ou capacidade para aferir juízos no processo de escolha ou, ainda, o efeito de distinguir-se mediante o raciocínio sobre os fatos que estão por acontecer ${ }^{26}$. Pessoa Jorge ensina que a culpa exprimiria a voluntariedade da conduta, um juízo de fato baseado no estado psíquico de seu autor ou, mais precisamente, um estado em que se denota, segundo a expressão italiana - diffeto de la inteligenzia - um verdadeiro defeito na inteligência das pessoas no processo de prevenção dos danos.

25 "Do latim praeventio, de praevenire (dispor antes, preparar antecipadamente, precaver)." (SILVA, 2006, p. 1092).

${ }^{26} \mathrm{O}$ autor ensina que, "Na ciência antiga, a importância da previsão foi acentuada apenas em medicina (HIPÓCRATES, Prognostikon). Galileu expunha esse conceito afirmando que "chegar ao conhecimento de um único efeito para suas causas abre-nos o intelecto ao entendimento e à certeza de outros efeitos, sem necessidade de socorrer à experiência" (Discorsi intorno a due move scienze, em Opere, Ed. Utet, II, p. 799). A previsão foi utilizada por Hume em sua crítica a causalidade: "Por sermos levados pelo costume a transferir o passado para o futuro, em todas as nossas inferências, sempre que o passado se manifesta regular e uniforme, esperamos o acontecimento com a máxima certeza e não damos ocasião a suposições contrárias”. (Inq. Conc. Underst, VI) Compte pôs esse conceito em primeiro plano com sua fórmula "Ciência, portanto previsão; previsão, portanto, ação" (Cours de Phil, pos, 1830, p.51). Heltz expressou-o nas palavras de abertura da Introdução a Prinzipien der Mechanik (1894): "O problema mais imediato e, certamente, o mais importante que nosso conhecimento da natureza permitir resolver é a previsão dos acontecimentos futuros, de tal modo que possamos organizar nossas atividades presentes de acordo com tais previsões”. Para Peirce, a previsão é a base da verdade prática da hipótese cientifica." (ABBAGNANO, 2007, p. 926). 
Bueres (2001, p. 339), nesse aspecto, ensina que "Hay aqui dos órdenes de sujeción del deudor situados en una relación de jerarquia el deber de previsión - que algunos lhaman "de diligencia" - es subordinamente, mientras que el deber de evitación - en ocasiones calificado como "de prudencia" - es subordinado."

Ora, certamente, o dever de evitar prejuízo envolve todo um procedimento de prevenção que, por sua vez, implica um processo de manipulação e análise dos dados destinados a apurar o que será necessário para evitar o dano. Tal mecanismo funcionará de forma mais eficiente na mente de uma pessoa mais esclarecida, visto que envolve um processo crítico e analítico mais refinado do que uma pessoa mediana ou medíocre terá condições de realizar. Bueres (2001, p. 340, grifo do autor) proclama que

[...] se da cuando el agente no previó el resultado, aunque pude preverlo con un esfuerzo de la atención - la culpa con previsión (o con representación), en conformidad con otro léxico - que adviene cuando el sujeto previó el daño, pero confió en su pericia con mientras a su evitación; no se entrega al azar.

A expressão significativa de Bueres, ao ensinar que o agente não se entrega ao azar, implica a dedução de que a pessoa diligente sempre buscará a forma mais eficiente para realizar seus atos, com o propósito de não gerar fatos lesivos ao interesse de outrem. Haverá situações em que a possibilidade da ocorrência do azar será mais evidente, por exemplo, a hipótese de alguém adentrar em um terreno onde há uma placa de advertência da presença de um animal feroz, propenso ao ataque - há um perigo iminente anunciado. $\mathrm{O}$ acesso ao local sem os cuidados necessários implica ao sujeito a ciência e a assunção dos riscos de ataque.

Bueres (2001, p. 326) destaca que, “...para evidenciar de forma virtual que para cumplir habría sido necesario emplear una diligencia mayor que la exigible en la emergencia". No caso exemplificado no parágrafo anterior, não basta apenas o cuidado normal que se emprega em situações de pequenos riscos de dano, mas, em razão da magnitude, exigir-se-á um cuidado especial - uma diligência acima do normal em relação àquela em que o agente normalmente utilizaria.

\section{A NEGLIGÊNCIA COMO INDICATIVO DA CULPA PREPONDERANTE NOS CÓDIGOS CIVIS ALIENÍGENAS DIANTE DA INCURIA DOS AUTORES}

A negligência sempre foi tratada nos diversos códigos civis como um descaso extremo na conduta das pessoas. É sabido que a ordem social exige dos agentes uma conduta de acordo com as normas jurídicas e os costumes de ordem e civilidade dos seus atores; a vida em sociedade impõe a todos o comportamento ditado pelo jurista romano 
Paulus, sedimentado nas regras seculares de vivere honeste, sum cuique tribuere e neminem laedere.

O art. 2.050 do Código Civil italiano proclama que: "Chiunque cagiona danno ad altri nellos volgimento di un'attività pericolosa, per sua natura o per la natura dei mezzi adoperati, e tenuto al risarcimento, se non prova di avere adottato tuttele misurei donee a evitare il danno." (DI MINAJO, 1997, p, 467, grifo nosso).

A parte final do texto indica uma conduta negligente do agente, visto que este omitiu ao adotar todas as medidas idôneas para evitar o dano; portanto, cumpre às pessoas o dever de observar atentamente sua conduta perante terceiros, com o propósito de proceder de forma a evitar a ocorrência de uma conduta ilícita, suscetível de causar dano a outrem.

Em situação semelhante, o art. 2.054 do Código citado prescreve uma regra de conduta diligente do agente ao prescrever que: "Art. 2.054: Il conducente di um veicolo senza guidadirotaie è obbligato a risarcire il danno prodotto a persone o a cose dalla circolazione del veicolo, se non prova di aver fatto tutto il possibile per evitare il danno." (DI MINAJO, 1997, p, 421, grifo nosso).

Logo, caberá ao agente culpado demonstrar que adotou todos os procedimentos previsíveis para evitar o dano ou, ainda, que não negligenciou a sua conduta de atenção e cuidado na direção do seu veículo.

Fica inequívoca da leitura, de ambos os dispositivos, a inserção de normas de conduta de diligência e de prudência na prática social dos atos praticados no ambiente coletivo. Nos Estados da commom law, é conhecida a expressão tort law, que corresponde àquela parte do Direito que se ocupa dos atos ilícitos cometidos por pessoas singulares e coletivas; todavia, não podem ser considerados crimes nem incumprimento de contratos (breach of contract).

A finalidade mais importante da tort law destaca-se em três vertentes: (1) compensar o lesado (compensate the victim); (2) desencorajar o comportamento negligente (deter negligence); e (3) fomentar o comportamento diligente (encourage due care). Entre as vertentes apontadas, destacam-se o desencorajamento do comportamento negligente e a fomentação do comportamento diligente do agente. As ideias que se extraem do mens legis, ao destacar as duas vertentes, são inequívocas. A primeira é direcionada para desestimular o comportamento irresponsável e inconsciente do agente; a segunda tem o propósito de induzir e/ou fomentar a adoção de conduta precavida, sempre inspirada no propósito de não gerar danos de qualquer natureza. Pelos motivos expostos, a punição do ofensor terá como objetivo reprimir a conduta negligente que não se encontra de acordo com as regras sociais.

$O$ art. 2.323 do Código Civil chileno prescreve que "El dueño de un edificio es responsable a terceros (que no se hallen en el caso del artículo 934) de los daños que ocasione su 
ruina acaecida por haber omitido las necesarias reparaciones, o por haber faltado de otra manera al cuidado de un buen padre de familia." (CHILE, 1997, p. 641).

A regra acima transcrita relata o dever de cuidado ou de diligência do dono sobre as suas coisas - responsabilidade pelo fato da coisa - estabelecendo que esse comportamento deve ser equivalente ao empregado por um bom "pai de família" nos cuidados impostos como necessários pela ordem jurídica.

A negligência, segundo reporta o art. 2.329 do Código Civil chileno, - "Por regla general todo daño que puede imputarse a malicia o negligencias de otra persona, deve ser reparado por ésta" - assume relevância em virtude dos seus nefastos efeitos no ambiente coletivo. O negligente será punido pela ausência do cuidado necessário imposto às pessoas, que devem empregar nas relações inter-humanas (CHILE, 1997, p. 643).

Nessa ordem de pensamento, o art. 2.319 do Código Civil chileno prescreve que "No son capaces de delito o cuasidelitos los menores de siete años ni los dementes, pero serán responsables de los daños causados por ellos las personas a cuyo cargo estén, si pudiere imputarseles negligencia." (CHILE, 1997, p. 640, grifo do autor).

Faz-se necessário destacar o dever que as pessoas responsáveis por menores e incapazes têm de cuidar destes, dado que estão sob a sua guarda e dependência. A omissão do dever de guarda torna evidente a negligência do agente e, portanto, o dever de responsabilidade em face da ausência das cautelas que lhe eram imputadas em razão da omissão no dever de vigilância necessária.

Os parâmetros adotados pelo Código Civil português (LIMA; VARELA, 1987, p. 470) não destoam da linha de conduta das demais codificações ao observar que a diligência e a negligência foram tratadas em conformidade com os fundamentos elaborados pelos tratadistas franceses ${ }^{27}$. $\mathrm{O}$ art. 487, §1º, da referida Lei (LIMA; VARELA, 1987, p. 488) prescreve que "A culpa é apreciada, na falta de outro critério legal, pela diligência de um bom pai de família, em face das circunstâncias de cada caso”.

O modelo padrão romano tornou-se a causa inspiradora de toda a codificação civil universal $^{28}$, o que demonstra que, nos códigos civis dos diversos Estados, predomina o princípio da conduta diligente do pai de família responsável pela condução

\footnotetext{
${ }^{27}$ De forma coerente com a prescrição contida no caput do artigo 483, Pires de Lima e Antunes Varela, na obra citada, proclamam que, "O elemento básico da responsabilidade é o facto do agente - um facto dominável ou controlável pela vontade, um comportamento ou uma forma de conduta humana -, pois só quanto a factos desta índole têm cabimento a idéia da ilicitude, os requisitos da culpa e a obrigação de reparar o dano, nos termos em que a lei a impõe.” (LIMA; VARELA, 1987, p. 471).

${ }^{28}$ Os autores nominados destacam que, "A referência expressiva ao bom pai de família acentua mais a nota ética ou deontológica do bom cidadão (do bonus cives) do que do critério puramente estatístico do homem médio. Quer isto significar que o julgamento não está vinculado às práticas de desleixo, de desmazelo ou de incúria, que porventura se tenham generalizado, se outra for a conduta exigivel dos homens de boa formação e de são procedimento." (LIMA; VARELA, 1987, p. 489).
} 
da instituição familiar; a base da sociedade moderna, a exemplo dos costumes presentes na Roma Antiga, sedimentada no pater familiae ${ }^{29}$.

Os pontos de ligação entre textos de diferentes codificações demonstram a inequívoca correlação existentes entre elas, ao destacar o necessário cuidado na realização de atos perante a ordem social, que poderão causar danos de diversas magnitudes. Como resultado, surge a necessidade de cautela, cuidado, prudência, diligência e atenção que uma pessoa responsável deve possuir em relação aos demais, sempre norteada pela bússola contida no princípio neminem laedere.

Nos campos de estudo de ética e filosofia, a diligência é considerada a virtude de perseguir objetivos e preservar os bons princípios, inerentes às pessoas que vivem no mundo dos valores. Nessa linha, o art. 483 do Código Civil lusitano prescreve que, "Aquele que, com dolo ou mera culpa, violar ilicitamente o direito de outrem ou qualquer disposição legal destinada a proteger interesses alheios fica obrigado a indemnizar o lesado pelos danos resultantes da violação." (LIMA; VARELA, 1987, p. 470, grifo nosso).

O texto final do referido artigo identifica a necessidade de o agente demonstrar que foi extremamente prudente e cauteloso, no sentido de evitar o dano que se concretizou a despeito do seu comportamento diligente. As referidas circunstâncias demonstram a necessidade de que a conduta da pessoa que vive em sociedade prescreve comportamentos de respeito e consideração em relação às demais pessoas que vivem no ambiente social.

Por sua vez, o Código Civil chileno, por meio do art. 2.319, destaca que "No son capaces de delito o cuasidelito los menores de siete años ni los dementes; pero son responsables de los daños causados por ellos las personas a cuyo cargo estén, si pudiere imputarseles negligencia."(CHILE, 1997, p. 640, grifo nosso).

No mesmo sentido, o art. 2.329 prescreve que, "Por regla general todo daño que puede imputarse a malicia o negligencia de otra persona, debe ser reparado por ésta." (CHILE, 1997, p. 643, grifo nosso). A partir da análise desses dois dispositivos, concluise que a inserção da negligência implica a adoção de cuidados no caso em que ocorrer a tutela - culpa in vigilando, ou seja, daquele que possui o dever de vigilância presente na teoria da guarda. No segundo caso, o dever de cautela será imposto àquele que, mediante ações públicas - como disparar de forma imprudente arma de fogo em local público, remover galhos de árvores em via pública ou que seja obrigado a construir ou

\footnotetext{
29"Este método es el más apropiado para determinar, referidos al caso concreto, el límite conceptual de la culpa, en las genuinas fuentes romanas significando en homo diligens est et studiosus paterfamilias, cuius personam incredibile est in aliquo facile errasse, aunque ha servido también, con cierta desorientación, para deslizarse por la trillada senda de las deducciones conjecturales y sostener, cual Levi que la culpa no es más que un errrore su quella che possono esser consequenze della proprie asioni comissive ed omissive."(SARRIÓN, 1993, p. 413).
} 
reparar aqueduto em via pública - tem a obrigação de evitar a ocorrência de qualquer dano aos que transitam pelo local. A mera negligência que produz dano impõe ao causador o dever de reparar os prejuízos decorrentes do ato desidioso. Tais circunstâncias demonstram o dever de diligência que deve estar presente no modo de agir das pessoas em situações dessa magnitude.

O que se destaca na sociedade moderna é um aumento desmesurado de danos, cuja maioria decorre do descuido, do desleixo, da incúria, da omissão ao dever de cuidado e da preguiça nos tratos sociais; enfim, da ausência de uma conduta de atenção e percepção durante todos os momentos em que o indivíduo se encontra no ambiente social. Pode-se afirmar que se vive na "época da negligência", ocasionada pelos infindáveis instrumentos de tecnologia que se encontram ao seu redor - celulares, notebooks, vídeos, equipamentos de som conectados à audição, exposições comerciais, vídeos na via pública, movimentos de veículos sofisticados e poluição sonora de grande magnitude, entre inúmeros outros instrumentos. Todos esses elementos distraem a atenção das pessoas; seres conectados com as banalidades e desconectados com a realidade. Por resultado, tornam-se negligentes nos pontos mais importantes da existência, nos quais deveriam comportar-se com o maior grau de atenção e prudência.

\section{A CONDUTA DO BONUS PATER FAMILIAE}

A ideia de um padrão de conduta que servisse de modelo para o homem comum na Roma Antiga surgiu para que o comportamento do cidadão romano fosse vinculado ao dever-ser da pessoa em face dos códigos de ética vigentes naquele período. Miranda (1954, p. 254) alude ao fato ao afirmar que "o homem normal, o homem diligente, para o patriarcalismo do direito romano, havia de ser o bom pai de família”. O modelo padrão instituído seria uma forma de estabelecer um procedimento normativo moral que se incorporasse aos hábitos e costumes das pessoas naquele momento histórico ${ }^{30}$. Essa proposta surgiu em uma sociedade que elaborava modelos jurídicos que se perpetuaram no curso da civilização, de forma a exercerem importantes influências na estrutura jurídica da sociedade moderna ${ }^{31}$ - tais como a Lei das Doze Tábuas e o Código de Justiniano ${ }^{32}$.

\footnotetext{
30 "Este método es el más apropriado para determinar, referido al caso concreto, el límite conceptual de la culpa, en las genuínas fuentes romanas, significando en bono diligens est et studiosus paterfamilias, cuius personam incredibile est in aliquo facile errasse, aunque ha servido también, con cierta desorientación, para deslizarse por la trillada senda de las deducciones conjeturales y sostener, cual Levi que la culpa no es más que "un erorre su quella che possono essere consequenze della proprie azioni comissive ed omissive." (SARRIÓN, 1993, p. 413).

${ }^{31}$ Meirelles (1990, p. 172) ao fazer alusão à A. J. Arnaud, sobre texto contido em "Critique de la Raison Jurídique", p. 27, o autor enfatiza que: "A razão jurídica é o motor em virtude do qual um sistema
} 
Não se pode admitir, em pleno século XXI, um padrão único de comportamento humano no ambiente social, formado atualmente por uma multiplicidade de fatores de ordem social, filosófica, científica e ideológica distantes da época romana. Farias, Braga Netto e Rosenvald (2015, p. 176) ensinam que

Obviamente, não se trata mais do bônus pater família, pois em coletividades plurais e essencialmente heterogêneas, seria idílico acreditar que exista apenas um determinando comportamento paradigma de comportamento virtuoso e que todas as demais formas de agir desconformes a esse supermodelo estariam desguarnecidas pelo sistema jurídico.

Não se deve descurar que essa ideologia comportamental se encontra presente na sociedade contemporânea por tratar-se de conduta que prima pela postura de comportamento adequado para cada modelo de relação - especialmente no campo das relações obrigacionais. Bueres (2001, p. 327, grifo nosso) assinala que:

Por ende, aunque la obligación este sometida a la regla habitual del buen padre de familia - o del modelo del hombre cuidadoso, previsor, etcetera - (culpa levis), el dolo actúa y es relevante pese a que se manifieste en el infracción de un grado de diligencia inexigibles - por ejemplo, una quam in sui.

O que se observa nas relações obrigacionais é uma conduta de moralidade instituída pelo legislador romano ao dispor, por meio do pacta sunt servanda, sobre uma regra de comportamento de respeito e consideração entre os contratantes para cumprimento dos contratos celebrados. Ora, para ocorrer essa situação, torna-se necessário que as partes contratantes conheçam as exigências necessárias ao cumprimento das obrigações ou, ainda, que não possam omitir-se no dever de conhecer os limites e os efeitos da obrigação pactuada; logo, ninguém é obrigado a contratar, mas quem contrata é obrigado a cumprir o que foi avençado. Essa é uma regra de diligência no momento da celebração do contrato e da formalização da conduta obrigacional.

O que se cuida, no caso em tela, é um "estado de consciência" de que o dever insculpido na regra alterum non laedere se encontra impresso na intimidade da conduta da pessoa, de agir no ambiente social sem causar qualquer tipo de dano a terceiros, ou seja, observando as regras de conduta social impregnada teologicamente nas pessoas.

jurídico se organiza de modo coerente e próprio para realizar certos fins. A perspectiva teleológica é inseparável do aspecto estrutural do sistema jurídico".

${ }^{32} \mathrm{O}$ autor que cita texto de Orlando de Carvalho, extraído da sua obra "A Teoria Geral da Relação Jurídica", p. 54: "O sistema de exposição é um sistema de educação jurídica, quer dizer, um sistema de comunicação da matéria da lei e um sistema de persuasão sobre o interesse da lei. Daí uma acentuação através dele dos princípios mais importantes da matéria normativa - o que dá ao sistema externo, e à sua arquitetura, um indiscutível relevo para a compreensão do ordenamento dos seus valores, do seu projectos ideológicos e sociológicos, numa palavra, da sua táctica e da sua estratégia”. (MEIRELLES, 1990, p. 172). 
Para isso, deve-se portar sempre de acordo com as regras de boa convivência social: de não fazer a outrem o que não se quer que o outro faça a si. Bueres (2001, p. 329) pontifica que,

[...] por otra parte, es inatacable que la culpa no es sólo descuido, una incuria, una desatención (mera relación sicológica) - lo que en el Derecho anglosajón se gráfica al señalarse que the diligence is state of mind -, sino que es una conducta (por cierto que calificada).

Por fim, anota-se um estado mental presente na estrutura psicológica da pessoa, produto da harmonia que deve reinar na convivência social, diante das múltiplas relações normatizadas por regras fundamentais de valor. $O$ homem é produto do meio em que vive, quando incorpora à sua personalidade as normas fundamentais e condutas que regem a sociedade organizada.

\section{A NEGLIGÊNCIA PERANTE OS TRIBUNAIS BRASILEIROS}

Os Tribunais brasileiros, de forma reiterada, destacam a negligência como uma das culpas preponderantes na produção de acidentes e danos de diversas magnitudes. Denota-se que grande parte dos acidentes de trânsito são tributados ao uso de celulares, quando a pessoa está dirigindo nas vias públicas. As distrações decorrem de motoristas que fumam durante a condução do veículo ou, ainda, que prestam a atenção em fatos informados nos celulares ou decorrentes da ausência da atenção necessária no tráfego. Por sua vez, em caso paradigmático decidido pelo STJ, pode-se observar que a negligência do hospital foi causa eficiente para o gravíssimo quadro resultante do comportamento desumano e absolutamente irresponsável de profissionais. $\mathrm{O}$ fato relata que

Ação de compensação por danos morais, devido à negligência de atendimento à agravada, vítima de acidente que resultou num "trauma raquimedular". Afirma que em razão da demora no atendimento o trauma progrediu para quadro de paraplegia”. (In STJ - AgInt no AREsp 1.383.479/SP - Rel. Ministra NANCY ANDRIGHI - TERCEIRA TURMA - julgado em 20.05.2019 -DJe 22.05.2019).

Em situação diversa, a omissão dos cuidados necessários do Tabelião propiciou a nulidade absoluta do ato jurídico realizado, demonstrando efeitos desastrosos produzidos por quem tem o dever de cuidado indispensável na lavratura de ato de grande magnitude, com o propósito de oferecer a necessária segurança jurídica esperada de atos notariais. No caso em exame, ocorreu uma venda a non domino, quando foi celebrada a venda de imóvel com base em procuração com qualificação errônea dos 
outorgantes, fato que demonstrou a negligência do cartório e resultou em fraude. $\mathrm{O}$ texto da decisão relata:

Escritura de compra e venda realizada com base em procuração na qual constam nomes incorretos do casal proprietário troca de numeração de documentos pessoais, utilização de número de identidade de outro Estado. Questões fático-probatórias. Insindicabilidade. Negligência do Tabelião que, ao confeccionar a escritura pública de compra e venda, não conferiu os dados dos supostos alienante. (In STJ - REsp 1.748.504/PE - Rel. Ministro PAULO DE TARSO SANSEVERINO - TERCEIRA TURMA - julgado em 14.05.2019 DJe 21.05.2019).

A situação sub examinis identifica, de forma solar, a atitude omissiva do notário que deixou de observar, com a diligência necessária, os elementos informativos verídicos e correspondentes à realidade da situação, para então proceder à lavratura do ato notarial. No caso examinado, denota-se a evidência dos efeitos extremamente lesivos que a falta de cuidado acarretou para a vítima e para a sociedade.

Quando se trata de negligência médica, o resultado agrava-se, na medida em que coloca em risco a vida do paciente. Nessas hipóteses, há erros médicos irreversíveis, cujos resultados geram, em geral, perdas e danos de expressiva magnitude, como demonstrado no caso sub examinis. Segundo decisão do STJ,

O homicídio culposo por erro médico restou reconhecido pela negligência do
tratamento adequado, incidindo sem bis in idem a majorante da inobservância
de regra técnica, não apenas pela falta ao atendimento exigivel para a situação,
mas também pela realização de procedimento cirúrgico de grande porte em
clínica que se sabia não possuir estrutura adequada”. (In STJ - AgRg nos EDcl
no REsp 1.661.283/PA - Rel. Ministro NEFI CORDEIRO - SEXTA TURMA
- julgado em 19.03.2019 -DJe 26.03.2019).

Por sua vez, a omissão do Estado, em virtude da sua negligência no poder de atuar e fiscalizar, gera danos graves, especialmente tratando-se de danos sociais de grande magnitude; a omissão do Estado - citem-se os casos de rompimento das barragens de Mariana e de Brumadinho no Estado de Minas Gerais, que produziram danos pessoais (mortes), danos morais e danos materiais, bem como prejuízos ambientais, com expressivas repercussões nacionais e internacionais. Diante dessas realidades, ficou extreme de qualquer dúvida a omissão do Estado, na modalidade de negligência, ao emitir alvarás, licenças ambientais, fiscalizar e monitorar as construções realizadas por meio do exercício irregular do poder de polícia. O dever do Estado de impor e determinar o impedimento da construção é inerente ao serviço prestado. Não se justifica que, após o impedimento da edificação, o Estado seja obrigado a impor a demolição do que foi construído de forma irregular e contrário aos regulamentos vigentes.

Pelas razões ora expostas, o Superior Tribunal de Justiça considerou manifestamente desproporcional e irrazoável a determinação de demolição em obra, 
cujo dever do Estado era o de proibir e impedir a edificação. Nessa direção, o STJ decidiu o seguinte:

Ao considerar a demolição "medida manifestamente desproporcional e irrazoável", sobretudo em face da omissão, "descaso e negligência" (destaques do autor) do Município/réu em fiscalizar e permitir a ocupação desordenada da área, o aresto recorrido se aproxima da compreensão já externada nesta Primeira Turma, em precedente no qual ficou assentado que, quando o Tribunal local, à luz das peculiaridades do caso concreto, leva em conta a omissão do Poder Público Municipal em fiscalizar a área e a desproporcionalidade da demolição, o acolhimento do especial para divergir das razões ali lançadas esbarra no óbice inserto na Súmula 7 do STJ, por exigir inevitável revolver de aspectos fático-probatórios dos autos". (In STJ - AgInt no REsp 1.387.379/SC - Rel. Ministro GURGEL DE FARIA - PRIMEIRA TURMA - julgado em23. 10/2018 -DJe 22.11.2018).

Diante das situações fáticas e reais mencionadas, é incontestável que o procedimento omissivo, na modalidade de negligência, produz efeitos danosos expressivos às vítimas e à sociedade. Por essa simples conclusão, a negligência traduz um procedimento desidioso do agente que é, por sua vez, resultado de um comportamento incompatível com as regras jurídicas e sociais de boa convivência, que são indicativas da consciência do dever/ser e que constituem fatores determinantes para as pessoas preparadas para viver em sociedade.

\section{OS GRAVES EFEITOS EM FACE DA NEGLIGÊNCIA DO AGENTE}

É plausível concluir que o fator determinante dos efeitos da negligência se refere ao extenso grau de consequências produzidas pela atividade omissiva, na modalidade de negligência. A omissão no dever de conduta, em face da incúria do agente, leva, na maioria dos casos, a resultados danosos para as vítimas. Não se justificam atitudes dessa modalidade no século XXI, no qual impera o conhecimento científico, tecnológico e jurídico, cujo acesso dá-se de forma imediata pelos meios de informação. Para saber os efeitos da sua ação ou omissão, o agente deve ter o necessário cuidado em observar os seus resultados.

A reiterada preguiça das pessoas na análise dos efeitos das ações, como demonstrado, é o resultado da desídia e da incúria do homem no século do conforto e da comodidade. Pensar e ponderar são considerados perda de tempo ou a falta dele, levando-se em consideração que os equipamentos modernos realizam uma gama de atividades que antes eram exclusivamente relegadas à atividade exclusivamente laboral. Tal preguiça intelectual é o resultado da acomodação do ser humano diante de uma 
sociedade alienada da sua vocação de construir um mundo onde imperam a igualdade e a observância dos valores fundamentais que direcionam a civilização ${ }^{33}$.

No âmbito dessa linha de intelecção, podem-se observar algumas decisões prolatadas, particularmente pelo STJ, que revelam o elevado grau de negligência de agentes, que produziram efeitos nocivos expressivos. Nesse particular, constata-se, por meio da análise do REsp. 1.775.010/TO do STJ, prolatado em 02.04.2019, relatado pelo Min. Raul Araújo, da 4a. Turma. Em tal situação, evidencia-se que o agente causador do dano lesivo negligenciou uma norma de conduta necessária na condução do seu veículo, exatamente com o propósito de evitar danos e assumir risco de produzilo em face do seu descaso:

O Tribunal de origem, com fundamento nas provas documental e pericial, concluiu que o recorrente agiu com negligência ao transitar em velocidade incompativel com a segurança do trânsito e, devido ao estouro do pneumático dianteiro, invadiu a contramão da via, atingindo, por consequência, o veículo da vítima.

Em situação diversa, o STJ, por meio do julgamento do REsp 1.661.283/PA, da lavra do Min. Nefi Cordeiro, prolatado em 19.03.2019, entendeu o seguinte:

O homicídio culposo por erro médico restou reconhecido pela negligência do tratamento adequado, incidindo sem bis in idem a majorante da inobservância de regra técnica, não apenas pela falta ao atendimento exigível para a situação (destaque do autor), mas também pela realização de procedimento cirúrgico de grande porte em clínica que se sabia não possuir estrutura adequada (grifo nosso).

O destaque que se observa se refere à circunstância da inobservância de regra técnica, fato que denota o descaso do profissional e que se agrava em face do fato de que havia conhecimento da inadequação estrutural da clínica. Ora, se o médico tinha conhecimento desses fatos importantes, por que motivo não tomou as cautelas necessárias para preservar, como se impunha, a integridade física do seu paciente, sabendo dos resultados que adviriam no procedimento cirúrgico?

33 O autor nos ensina sobre a razão ao afirmar em sua obra que é a nossa bússola para analisar corretamente os caminhos que nos cabe seguir, desviando-se, tanto quanto possível, dos infortúnios e dos incômodos que nos causam as decisões irrefletidas ou que negligenciamos em analisar criticamente, daí por que afirma, "muitos autores atuais confundem a defesa iluminista da razão como a afirmação implausível de que os seres humanos são agentes perfeitamente racionais. Nada poderia estar mais distante da realidade histórica. Pensadores como Kant, Baruch Espinosa, Thomas Hobbes, David Hume e Adam Smith foram psicólogos inquisitivos e mais do que conscientes das nossas paixões e fraquezas irracionais. Asseveravam que só expondo as fontes comuns de insensatez poderíamos ter esperança de superá-las. a aplicação deliberada da razão era necessária justamente porque nossos hábitos comuns de pensamento não eram muito razoáveis.” (PINKER, 2018, p. 27). 
Outro momento diverso relata caso de extrema negligência, com gravíssimos efeitos, contido no REsp 1.771.881/PR, relatado pela Min. Nancy Andrighi, da 3a . Turma, julgado em 06.12.2018, cuja ementa transcreve-se adiante:

\begin{abstract}
Ação de indenização por danos materiais e compensação por danos morais, ajuizada em face de hospital e médica pediatra, devido à negligência na exposição do recém-nascido prematuro a excessivas cargas de oxigênio sem proteção aos olhos e falta de informações corretas para seu tratamento. No particular, o acórdão recorrido pontuou que o bebê recebeu alta após vinte e oito dias do nascimento, havia tempo hábil para uma avaliação com oftalmologista e neurologista que, caso tivesse sido feita, poderia ter mudado o destino da criança, que fez o exame somente com sete meses de vida, quando a cegueira já era irreversível.
\end{abstract}

Os casos expostos relatam os gravíssimos efeitos decorrentes de atos de negligência, que resultaram em danos de grande monta às vítimas, em alguns deles, de natureza irreversível. Os presentes fatos revelam, pela sua evidência e quantum satis, que o descaso, a desatenção, a incúria e a falta de análise ou de reflexão devem ser considerados como uma culpa de natureza relevante, visto que refletem o despreparo e a insensibilidade dos agentes pelos danos causados em face do seu ato de desamor e de respeito ao outro. Por essa razão, impõe-se reprisar a afirmativa de Paulo, o romano,

\title{
magna negligentia culpa est: magna culpa dolus est.
}

É inadmissivel que a sociedade moderna conviva com pessoas dotadas de tal nível de insensibilidade, considerando os efeitos nefastos ocasionados às vítimas decorrentes dessa desídia. Nunca, como nos dias presentes, tornou-se imprescindível que os comportamentos das pessoas no ambiente social sejam pautados por cuidados especiais, em respeito ao princípio dos direitos fundamentais que envolvem o ser humano em sua dimensão espiritual. A dignidade da pessoa humana configura um princípio relevante que enaltece e protege os indivíduos em toda a sua magnitude. É extremamente doloroso e inadmissível que uma criança recém-nascida, em condições físicas perfeitas, seja condenada a viver na escuridão da vida, por causa da negligência particular médica e hospitalar. O fato revela uma situação, dentre muitas outras, que demonstra o sofrimento extremo da vítima e de seus familiares por ser condenada a permanecer na zona cinzenta da vida durante o resto da sua existência. A circunstância em que ocorreu o fato revela negligência grave, que resulta na responsabilidade consequente do agente causador.

Ao abordar o tema em estudo, Miranda (1954, p. 263, grifo do autor) elucida que "A negligência grave supõe que o agente podia prever o resultado e o previu". $\mathrm{Na}$ sequência, conclui: "Na culpa grave, previu-se e não se quis; porque se quis, dolo há, e não só culpa lata”; portanto, a negligência, nessas situações, transmuta-se para uma culpa grave - a maior delas! As pessoas que convivem em sociedade têm, necessariamente, 
consciência do respeito que se deve tributar ao outro. Ninguém se escusa de cumprir o mandamento de convivência que impõe regras de diligência e atenção especial no trato dos interesses alheios.

\section{CONSIDERAÇÕES FINAIS}

O homem é educado por meio dos instrumentos sociais presentes na família e nas normas insculpidas nos ordenamentos jurídicos para viver em sociedade. Aristóteles já identificava esse animus coletivo insculpido nos seres humanos; todavia, para cumprir os ditames preceituados pela ordem jurídica, que, no dizer do estoico Crisipo, é a rainha de todas as coisas, torna-se necessário reconhecer que a vivência no ambiente pluralístico está associada à diversidade. Afinal, os seres humanos são identificados por meio das diferenças que qualificam a sua personalidade. Nesse processo de convivência, cumpre ao ser humano observar a regra basilar inscrita na laje da sua consciência, presente no princípio romano do axioma neminem laedere.

O dever de não causar lesão a outrem prescreve uma norma moral de conduta social. Afinal, a culpa, em suas modalidades de imperícia, imprudência e negligência constituem causas violadoras desse princípio, que geram danos de expressiva magnitude. É certo que a proposta de pesquisa se deteve na análise da culpa na modalidade da negligência, por entender que se trata de conduta grave por parte das pessoas, decorrente de um proceder inadequado e desatento em face da realidade vivencial. Os seres humanos chamados para a vida comunitária têm o dever de saber o que se deve ou não fazer em face do outro. Vico já advertia que a noção de Direito nasce das profundezas da consciência popular e da sabedoria vulgar; conceitos impregnados em nossa alma que denunciam uma ideia do justo e do injusto, que se modela com base nas influências externas que governam nossas vidas.

Todas as pessoas são portadoras da falibilidade humana, ou seja, propensas a agir de forma errônea e contrária aos princípios valorativos que norteiam o ser humano. No entanto, em átimo de tempo, as pessoas agem de forma equivocada ou errônea, sem analisar as consequências dos seus atos. Diante dessas constatações, a falta de cautela, de cuidado, de diligência, de exação, de avaliação, de respeito aos direitos do próximo, de inobservância da prevenção, do individualismo e dos que se esquecem da presença do outro constituem procedimentos que geram efeitos lesivos diversos.

O negligente omite um dever de cautela e cuidado, não procede com a prudência ou com o desiderato necessário para evitar o dano provável. A negligência, segundo se entende, é a principal responsável pela infinidade de danos que ocorrem na sociedade moderna. Certamente, prejuízos poderiam ser evitados se as pessoas procedessem de forma diligente na prática de seus atos. Nesse caso, omitiram um dever de exação. 
É inegável que a omissão na modalidade de negligência é ato humano, visto que se opera no mundo jurídico por decorrência de comportamento das pessoas dotadas de discernimento para compreender o fato danoso e tomar as medidas necessárias para evitá-lo. Dessarte, a falta das cautelas necessárias nos atos que oferecem riscos evidencia a ocorrência de uma magna negligência ou de significativa expressão. Nessa modalidade de displicência, a pessoa omite uma conduta indispensável para evitar o dano a outrem, fato que demonstra a verdadeira ausência de cuidado em relação aos direitos fundamentais do próximo.

Portanto, o agente negligente, de forma insensível, nada fez para evitar o fato lesivo. Sua atitude é extremamente nociva para a sociedade, considerando que tinha o dever de conhecer previamente a ocorrência do fato danoso; todavia, manteve-se inerte e insensível diante dos efeitos ofensivos previstos. Nesse caso, torna-se responsável pelos danos produzidos em face da sua ação impregnada de nocividade. As pesquisas realizadas pelo Superior Tribunal de Justiça demonstram inúmeras situações em que a postura negligente do agente produziu danos expressivos, sendo uma grande parte deles de natureza irreversível. É com extremada razão que alguns jurisconsultos, entre eles Pontes de Miranda, situam a negligência grave ao lado do dolo.

Nessas situações, a falta de cuidado foi tão extremada que o agente procedeu como se tivesse a intenção de produzir o dano. Essa ausência de carinho, de atenção e de cuidado qualifica a pessoa que não se encontra preparada para conviver no ambiente social. $\mathrm{O}$ agente converte-se em um ser humano desconectado dos fatos sociais presentes em todos os segmentos da vida comunitária; submetem a situações de riscos a integridade das pessoas e os valores da sociedade, subvertendo-os por meio do seu comportamento desprovido de razão.

Portanto, a negligência, na sua modalidade magna, identifica uma culpa grave que produz danos expressivos e irreversíveis, constituindo uma das formas de culpa com efeitos nocivos mais repelidos pelo ordenamento jurídico. A sociedade contemporânea necessita de paz e confiança nos cidadãos conscientes e responsáveis, que contribuam para a construção de uma comunidade justa, ética e humana.

\section{REFERÊNCIAS}

ABBAGNANO, Nicola. Dicionário de Filosofia. São Paulo: Martins Fonte, 2007.

ALTAVILLA, Enrico. Psicologia Judiciária: o processo psicológico e a verdade judicial. 3. ed. Coimbra: Armênio Amado Editor, 1981. t. I. 
BIANCA, Carlos Massimo. Diritto Civile: la responsabilità. Milano: Giufrré Editore, 1994.

BUERES, Alberto. Derecho de Daños. Buenos Aires: Hammurabi, 2001.

BRASIL. Superior Tribunal de Justiça. Disponível em: htpp://www.stj.jus.br. Acesso em: 15 maio 2020.

CAVAlIERI FILHO, Sérgio. Programa de Responsabilidade Civil. 11. ed. São Paulo: Atlas S.A., 2014.

CHILE. Codigo civil. Santiago: Editorial Juridica de Chile, 1997.

DI MINAJO, Adolfo (ed.). Codice Civile: Com La Constituzione, Il Trattato C.E.E. e Le Principali Norme Complmenentari. 11 ed. Milano: DOTT. A. GIUFFRÈ EDITORE, 1997.

FARIAS, Cristiano Chaves de; BRAGA NETTO, Felipe Peixoto; ROSENVALD, Nelson. Novo Tratado de Responsabilidade Civil. São Paulo: Atlas, 2015.

GONÇALVES, Carlos Roberto. Direito Civil Brasileiro: responsabilidade civil. São Paulo: Saraiva, 2017. v. 4.

LIMA, Pires de; VARELA, Antunes. Código Civil Anotado. Coimbra: Coimbra Editora, Limitada, 1987. v. 1.

MEIRELLES, Henrique da Silva Seixas Meireles. Marx e o Direito Civil: para a crítica histórica do "paradigma civilístico". Suplemento do Boletim da Faculdade de Direito da Universidade de Coimbra, Coimbra, 1990.

MIRANDA, Pontes de. Tratado de Direito Privado. Rio de Janeiro: Editora Borsoi, 1954. Parte Geral, t. II.

NORONHA, Fernando. Direito das Obrigações. São Paulo: Saraiva, 2003.

PASSMORE, John. A Perfectibilidade do Homem. Rio de Janeiro: Topbooks Editora e Distribuidora de Livros Ltda., 2004.

PINKER, Steven. O Novo Iluminismo: em defesa da razão, da ciência e do humanismo. São Paulo: Companhia de Letras, 2018.

REPRESAS, Felix A. Trigo; MESA, Marcelo J. Lopes. Tratado de la Responsabilidad Civil. Buenos Aires: La Ley, 2004. t. I. 
RIZARDO, Arnaldo. Responsabilidade Civil. 3. ed. Rio de Janeiro: Forense, 2007.

SARRIÓN, Angel Martinez. Las Raíces Romanas de la Responsabilidad por Culpa. Barcelona: Bosch, Casa Editorial, 1993.

SCHREIBER, Anderson. Manual de Direito Civil Contemporâneo. São Paulo: Saraiva, 2018.

SILVA, De Plácido e. Vocabulário Jurídico. 27. ed. Rio de Janeiro: Forense, 2006.

TUNC, André. La Responsabilité Civile. Paris: Editora Economica, 1981.

VECCHIO, Giorgio Del. Lições de Filosofia do Direito. Tradução Antonio José Brandão. 5. ed. Coimbra: Armênio Amado Editor, 1979.

\section{NOTA}

Os Autores Clayton Reis e Irene Portela participaram em conjunto e de forma complementar para a concretização do presente artigo, tendo partilhado a definição do tema, dos objetivos do estudo científico, da metodologia, da orientação científica, da organização e da revisão do artigo. Coube ao Autor Clayton Reis a redação do artigos em português do Brasil, permitindo esta colaboração internacional. $\mathrm{O}$ artigo que ora se propõe é, portanto, uma obra de cunho coletivo.

Como citar este documento:

REIS, Clayton; PORTELA, Irene. Negligência grave: a falta da exacta diligentia. Revista Opinião Jurídica, Fortaleza, v. 18, n, 29, p. 285-317, set./dez. 2020. 